Magdalena Satora

\title{
Polityka Francji wobec ZSRR w kontekście problemów Morza Śródziemnego (1936-1937)
}

Sytuacja polityczna istniejąca $w$ Europie $w$ drugiej połowie lat trzydziestych zmuszała dyplomatów do starań o nakreślenie nowego porządku międzynarodowego w różnych częściach kontynentu. Tak było również w przypadku Morza Sródziemnego, którego znaczenie strategicznie znacznie wzrosło w okresie napięć spowodowanych atakiem włoskim na Etiopię w październiku 1935 r., a także wybuchem wojny domowej w Hiszpanii w lipcu $1936 \mathrm{r}$. Koncepcje nowych uregulowań dotyczących spraw tego akwenu, a także postulaty zmian umów zawartych w poprzednich latach znalazły się $w$ kręgu zainteresowań utworzonego w czerwcu 1936 r. francuskiego rządu Léona Bluma. Z punktu widzenia polityki zagranicznej prowadzonej w tym okresie przez Paryż miały one istotne znaczenie nie tylko z powodu konieczności ochrony granic państwa, ale również ze względu na potrzeby wynikające $z$ istniejących porozumień z państwami Europy Wschodniej, a głównie ze Zwıązkiem Radzieckim, z którym od maja 1935 r. łączył Francję układ o wzajemnej pomocy. Jego podpisanie było efektem największego zbliżenia w dwustronnych stosunkach od czasu pierwszej wojny światowej. Mimo to Francuzi ratyfikowali go dopiero w lutym 1936 r., co było wynikiem silnych sporów ugrupowań prawicowych i lewicowych. Wielka Brytania, mająca w latach trzydziestych coraz większy wpływ na politykę zagraniczną Paryża, okazywała wyraźne niezadowolenie ze zbliżenia francusko-radzieckiego od maja $1935 \mathrm{r}^{1}$. Niemcy wykorzystali jego ratyfikację jako pretekst do remilitaryzacji Nadrenii w marcu 1936 r. Wydarzenie to, a także brak zdecydowanej reakcji ze strony Paryża sprawily, że dotychczasowa pozycja Francji na arenie międzynarodowej została w istotny sposób osłabiona. Stworzony przez nią w latach dwudziestych system sojuszy obronnych okazal się być nieskuteczny. Wschodni partnerzy przestali mieć zaufanie do jej możliwości obronnych². Przed utworzonym po wyborach parlamentar-

${ }^{3}$ F. Delpla, Léon Blum face à lAllemagne nazie, [w:] Avenirs et avant - gardes en France XIX-XX siècles. Hommage à Madeleine Rebérioux, sous la direction de Vincent Duclert, Rémi Fabre et Patric Fridenston, Paris 1999, s. 296.

2 W maju 1396 r. otwarcie mówił o tym między innyni Nicolae Titulescu, stwierdzając, że jeżeli Francja nie byla w stanie obronic whasnych granic, nie można bylo liczyć na to, że będzie bronić 
nych z maja 1936 r. pierwszym rządem Frontu Ludowego we Francji stanęło więc zadanie znalezienia nowych gwarancji dla bezpieczeństwa granic kraju.

Fundamentami programu działań na arenie międzynarodowej, zaprezentowanego przez członków nowopowstałego gabinetu w Senacie i Izbie Deputowanych 23 czerwca $1936 \mathrm{r}$, miały być: bliskie współdziałanie z Wielką Brytanią, serdeczna przyjaźń ze Stanami Zjednoczonymi i aktywna współpraca z ZSRR ${ }^{3}$. Jako najważniejsze zadania stojące przed dyplomacją francuską wymieniano, obok podpisania nowego układu lokarneńskiego i stworzenia Paktu Naddunajskiego, również ręalizację projektu Paktu Śródziemnomorskiego ${ }^{\sharp}$. Deklarację podobnej treści Blum złożył 1 lipca w Genewie, gdzie powtórnie wymienil najważniejszych partnerów Francji, wśród których znalazł się Związek Radziecki'. Premier niejednokrotnie wyrażał przekonanie o tym, że pakt francusko-radziecki mógł odegrać bardzo istotną rolę w dążeniu do zachowania pokoju w Europie ${ }^{6}$. Dodatkowo, mówiąc o stosunkach z Moskwą, premier stwierdzał, że podpisany rok wcześniej dwustronny pakt o wzajemnej pomocy "wyszedł $\mathrm{z}$ użycia" i opowiadał się za jego „ożywieniem". Układ ten zakładał wsparcie w przypadku zagrożenia, zgodnie $z$ artykułem dziesiątym Paktu Ligi Narodów i natychmiastową reakcję zbrojną, jeśli druga strona zostałaby zaatakowana przez jakiekolwiek państwo w Europie. . Aby umowa ta mogła mieć praktyczne zastosowanie, konieczne było podpisanie dodatkowych umów międzysztabowych, regulujących warunki współpracy wojskowej. Dla realizacji zobowiązań konieczne było stworzenie moźliwości komunikacji między dwoma partnerami, co zapewnić mogły między innymi odpowiednie regulacje dotyczące żeglugi po Morzu Śródziemnym i w Cieśninach Czarnomorskich. Analiza działań rządu Bluma podejmowanych w tej dziedzinie pozwoli zatem na ukazanie jego stosunku do ZSRR jako sojusznika, a także na określenie znaczenia

interesów swoich aliantów - J. Paul-Boncour, Entre deux guerres. Souvenirs sur la III République, t. 3, Sur les chemins de la défaite 1935-1940, Paris 1946, s, 110; A. T. Komjathy, The crises of France's central europian diplomacy 1933-1938, New York 1976, s. 164.

${ }^{3} \mathrm{~J}$. Colton, Léon Blum, Paris 1967, s. 214.

${ }^{4}$ A. M. Brzeziński, Zagadnienia bezpieczeństwa zbiorowego $w$ Europie $w$ polityce zagranicznej Francji (1919-1939), Eódź 1992, s. 137.

${ }^{5}$ Documents Diplomatiques Français 1932-1939, 2-éme série: 1936-1939, Paris 1964-1970 (dalej: DDF, II), t. 2, dok. 379; J. Lacouture, Léon Blum, Paris 1977, s. 327.

${ }^{6}$ L. Blum, L'Oeuvre, t. 4, 1-ère partie, Du 6 févier 1934 au Front Populiare, Paris 1964, s. 360.

${ }^{7}$ Les Evénements survenus en France de 1933 à 1945. Témoignages et documents recueillis par la Commission d'enquete parlamentaire. Annexes; dépositions, Paris 1952, t. 1, s. 128; M. H. Michel, Le Front Populaire et l'USSR, [w:] Les Relations franco-britanniques de 1935 à 1939. Communications presentées aux colloques franco - britanniques tenus d: Londres (Imperial War Museum) du 18 au 21 octobre 1971, Paris (Comité d'Histoire de la 2 ème Guerre Mondiale) du 25 au 29 septembre 1972, Paris 1975 , s. 217.

${ }^{8}$ P. Renouvin, La Politique extérieure du premier minister de Léon Blum, [w]: E. Bonnefous, Histoire politique de la Troisième République, $\mathrm{t}, 6$, Vers la guerre: Du Front populaire à la Conference de Munich (1936-1938), Paris 1986, t. 6, s. 405.

${ }^{9}$ Documents Diplomatiques français 1932-1939, 1-ère série: 1932-1935, Paris, 1964-1966 (dalej: DDF, I), t. 10, dok. 273. 
jakie nadawano wschodniemu partnerowi w koncepcjach francuskiego systemu bezpieczeństwa. Dodatkowo, mimo ze zagadnienia te stanowily tylko niewielki fragment aktywności dyplomacji francuskiej w latach 1936-1937, pozwalają one wskazać niektóre cechy charakterystyczne całej polityki zagranicznej prowadzonej pod kierunkiem Bluma i ministra spraw zagranicznych w jego rządzie, Yvona Delbosa.

Od $1933 \mathrm{r}$. Turcja domagała się zmiany niektórych punktów umowy o statusie Cieśnin Czarnomorskich, podpisanych podczas konferencji w Lozannie w 1923 r., co motywowala koniecznością zapewnienia bezpieczeństwa swoich granic. Uregulowania lozańskie zakładały całkowitą ich demilitaryzację i zakaz wznoszenia przez Turcję fortyfikacji w ich rejonie, a także zabraniał przeprowadzania jakichkolwiek operacji wojennych $w$ cieśninach i przepływania przez nie okrętom państw wojujących. W czasie pokoju korzystać z tego szlaku mogly wszystkie statki, a jedyne ograniczenie dotyczyło tonażu okrętów państw nieleżących bezpośrednio nad Morzem Czarnym ${ }^{10}$. W kwietniu 1936 r. Turcja zgłosiła na forum Ligi Narodów postulat utworzenia nowej umowy o statusie Cieśnin Czarnomorskich. Jednoczesnie rząd turecki zwrócił się bezpośrednio do wszystkich państw - sygnatariuszy umowy podpisanej w $1923 \mathrm{r}$. Rosjanie, choć uczestniczyli w konferencji lozańskiej i podpisali zaproponowane wtedy porozumienie, ostatecznie nie ratyfikowali go, uważając, że nie gwarantowało ono bezpieczeństwa ich $\mathrm{kraju}^{11}$. Z tego powodu propozycja zmian wysunięta przez Ankarę spotkała się z ich zdecydowanym poparciem $^{12}$. Dnia $23 \mathrm{kwietnia} \mathrm{Francja} \mathrm{wyrazila} \mathrm{zgodę} \mathrm{na} \mathrm{przeprowadzenie} \mathrm{rozmów}$ o zmianie istniejących uregulowań, zaznaczając przy tym, że jej ocena poruszanego zagadnienia jest bardzo bliska brytyjskiej ${ }^{13}$. Przedstawiony przez Turcję projekt zakładał remilitaryzację strefy cieśnin, która zapewnić miała bezpieczeństwo tego kraju, a także ograniczenie możliwości żeglugi okrętów wojennych w okresach zagrożenia pokoju i $w$ czasie wojny ${ }^{14}$. Idea ponownego uregulowania spraw cieśnin ze względu na zmieniającą się sytuację polityczną i pojawiające się niebezpieczeństwa wojny została zaakceptowana przez zainteresowane rządy, dlatego zdecydowano się na zwołanie międzynarodowej konferencji, której celem byłoby podpisanie nowych konwencji. Pierwsze instrukcje francuskie $z$ nią związane, pochodzące z 12 maja 1936 r., napisane przez Pierra Flandina, przewidywały przyjęcie stanowiska identycznego z brytyjskim. Wiązać się to miało - według ministra - z wyraźną wspólnotą interesów, jaka łączyła oba kraje w tej sprawie ${ }^{\mathrm{i}}$.

Obrady konferencji rozpoczęly się 22 czerwca 1936 r. w szwajcarskim Montreux ${ }^{16}$. Uczestniczyli w niej przedstawiciele Francji, Wielkiej Brytanii, ZSRR,

19. H. Batowski, Między dwiema wojnami 1919-1939. Zarys historii dyplomatycznej, Kraków 2001, s. 74.

"Ibidem.

${ }^{12}$ DDF, II, t. 2, dok. 67 i 89.

${ }^{13}$ Ibidem, dok. 107.

${ }^{14}$ DDF, II, t. 2, dok. 57, 74 .

${ }^{15}$ Tbidem, dok. 202.

${ }^{16}$ Ibidem, dok. 337. 
Turcji, Rumunii, Grecji, Bułgarii, Jugosławii i Japonii. Już na początku dyskusji nastąpil powrót do istniejącego od XIX w. konfliktu angielsko-rosyjskiego w spra. wie cieśnin. Rosjanie twierdzili, że zakaz wpływania okrętów wojennych na Morze Czarne nie oznacza, że flota rosyjska nie mogłaby wpłynąć na Morze Śródziemne, Brytyjczycy byli natomiast zdania, że powinny istnieć identyczne ograniczenia dla przépływu w obie strony ${ }^{17}$. Przedstawiony przez nich projekt różnił się od początkowej propozycji tureckiej, popieranej przez ZSRR i zakładał wyznaczenie limitów tonażu dla okrętów wszystkich zainteresowanych państw ${ }^{18}$. Przedstawiciele Ankary poparli to stanowisko, stając w ten sposób w opozycji do postulatów zgłaszanych przez Rosjan. Delegat francuski, Jean Paul-Boncour zabrał glos $w$ dyskusji wymieniając punkty, które były istotne z punktu widzenia Francji. Najważniejszą $\mathrm{z}$ nich była - według niego - konieczność zapewnienia możliwości wy. wiązania się ze zobowiązań wynikających z Paktu Ligi Narodów i innych umów z nim związanych ${ }^{19}$. Było to wyraźne odniesienie do sojuszy łączących Francję z ZSRR i Rumunią. Reprezentujący Związek Radziecki Maksim Litwinow przedstawił propozycję konwencji zakładającą prawo wpływania okrętów na wody obu mórz, jeśli w grę wchodziłaby realizacja zobowiązań sojuszniczych, zgodnych $z$ zasadami Ligi Narodów ${ }^{20}$. Jego stanowisku przeciwstawiali się Brytyjczycy. Uważali oni, że jakiekolwiek odniesienia do umów regionalnych związanych z Paktem Ligi Narodów były zbędne. Przedstawiona przez nich kontrpropozycja uzaleźniała każdorazowe przepłynięcie okrętów przez cieśniny w czasie wojny od decyzji Rady Ligi ${ }^{21}$. Konflikt wydawał się bardzo trudny do rozwiązania, gdyż żadna $\mathrm{z}$ delegacji nie była gotowa do ustępstw. Litwinow stwierdził nawet w rozmowie z Paul-Boncourem, że Moskwie zależało przede wszystkim na zapewnieniu sobie pełnego bezpieczeństwa na Morzu Czarnym, dlatego gdyby musiała wybierać między całkowitym zamknięciem cieśnin a równością praw dla okrętów przepływających w obu kierunkach, zdecydowanie poparłaby pierwsze rozwiązanie. $\mathrm{Na}$ pytanie francuskiego rozmówcy o możliwości wypełnienia zobowiązań wynikających z paktu o wzajemnej pomocy, w przypadku zamknięcia szlaku morskiego łączącego oba kraje, komisarz odpowiedzial, że komunikacja drogą lądową przez terytorium Czechoslowacji wydawała się w tym wypadku wystarczająca ${ }^{22}$.

${ }^{17}$ Ibidem, dok. 348.

${ }^{13}$ Ibidem, dok. 443.

19 Ibidem, dok. 348.

${ }^{20}$ Ibidem, s. 647 - przypis wydawcy.

${ }^{21}$ Ibidem, dok. 421.

${ }^{22}$ Ibidem, dok. 358. Koncepcja organizacji szlaku komunikacyjnego, koniecznego dla realizacji postanowien francusko-radzieckiego układu o wzajemnej pomocy, prowadzącego przez terytoria państw Europy Środkowo-Wschodniej wysuwana była przez Rosjan przez caly okres trwania dwustronnych rozmów o umowach sztabowych, które miały przeksztalcić umowę z $1935 \mathrm{r}$. w rzeczywisty sojusz wojskowy. Brak możliwości realizacji tego postulatu z powodu zdecydowanego sprzeciwu Polski i Rumunii stał się jednym z powodów przerwania negocjacji w 1937 r. - DDF, II, t. 5, dok. 480; N. Jordan, The Popular Front and Central Europe: The Dillemas of French Impotence, 1918-1940, Cambridge 1992, s. 266. 
W trakcie dalszej części konferencji przedstawiciele Francji, Rumunii i ZSRR bronili stanowiska o konieczności zapewnienia realizacji wzajemnych zobowiązan sojuszniczych. Delegacje tych państw wspólnie ustalały szczegóły proponowanych $w$ tym zakresie rozwiązan ${ }^{23}$. Spotkania $z$ tym związane stworzyly mozliwość rozpoczęcia rumuńsko-radzieckich rozmów na temat paktu o wzajemnej pomocy, którą to ideę gorąco popierała Francja. Paul-Boncour został zaproszony do uczestnictwa w negocjacjach Nicolae Titulescu i Litwinowa ${ }^{24}$. W trakcie przeprowadzonych wtedy rozmów stworzono projekt umowy zakładającej rumuńską zgodę na przemarsz radzieckich wojsk w przypadku niemieckiego ataku na któregoś z aliantów ZSRR. Dokument miał również zawierać deklarację, zgodnie z którą żaden radziecki oddział nie miał pozostać na terytorium Besarabii - spornego dla obu krajów - po zakończeniu działań wojennych. Ostatecznie porozumienie to nie doszło do skutku $z$ powodu wątpliwości Litwinowa dotyczących sytuacji wewnętrznej w Rumunii, a także stanowiska Francji ${ }^{25}$.

W drugiej połowie lipca impas w rozmowach w Montreux został przelamany. Delegacja francuska zaproponowała rozwiązanie kompromisowe, zawierające zapis o paktach regionalnych, jednak przyjmujące pewne niewielkie poprawki zgłaszane przez różne kraje. Równolegle toczyły się dwustronne rozmowy brytyjsko-radzieckie, których celem było wypracowanie porozumienia w kwestiach, w których oba kraje były najbardziej aktywnymi oponentami. Francuski projekt tekstu został przedyskutowany z przedstawicielami Wielkiej Brytanii, ZSRR, Turcji 1 Rumunii, a następnie przedstawiony reszcie uczestników konferencji. Wszystkie państwa, mimo zgłaszanych zastrzeżeń, zgodzily się na przyjęcie tekstu francuskiego ${ }^{26}$. Obrady konferencji zakończono 20 lipca 1936 r. uroczystym podpisa niem nowej konwencji przewidującej całkowitą wolność żeglugi przez cieśniny dla wszystkich statków handlowych i różne prawa dla okrętów wojennych państw czarnomorskich i „nieczarnomorskich”. Jednostki wojenne pierwszych z nich mogły przepływać przez cieśniny bez ograniczeń, natomiast w przypadku innych krajów wprowadzono warunki odnoszące się do tonażu i rodzaju okrętów ${ }^{27}$.

Działania dyplomatów francuskich podczas konferencji w Montreux były jedną z pierwszych prób realizacji założeń polityki zagranicznej zaproponowanych przez Bluma i Delbosa. Mimo planów przyjęcia identycznego stanowiska z brytyjskim, stworzonych przez poprzedniego ministra spraw zagranicznych, delegat francuski przeciwstawił się propozycjom Londynu i postawił sobie za główny cel ochronę interesów wynikających z sojuszy łączących Francję z Rumunią i Związkiem Radzieckim. Współpraca ze wschodnimi partnerami okazała się być skuteczna, podobnie jak przyjęcie przez Francję roli mediatora w konflikcie bry-

${ }^{23} \mathrm{DDF}, \mathrm{II}, \mathrm{t} .2$, dok. $42 \mathrm{l}$.

${ }^{24}$ J. Paul-Boncour, op.cit., s. 59; Les Evénements, t. 3, s. 797.

${ }^{25}$ N. Jordan, op.cit, s. 193.

${ }^{26}$ DDF, II, t. 2, dok. 456.

${ }^{27}$ DDF, Il, t. 3, dok. 146; A. Skrzypek, Strategia pokoju. Radziecka polityka zbiorowego bezpieczeństwa $w$ Europie 1932-1939, Warszawa 1979, s. 265; A. M. Brzezinski, op.cit., s. 143. 
tyjsko-radzieckim, z czego ogromne zadowolenie wyrażał Delbos w swoim komentarzu do umowy podpisanej przez uczestników konferencji w Montreux. Minister stwierdził również, że przyjęte rozwiązania były $z$ punktu widzenia polityki francuskiej najkorzystniejszymi $\mathrm{z}$ możliwych ${ }^{28}$.

Przykładem zdecydowanie odmiennych działań dyplomacji francuskiej w drugiej połowie 1936 r. okazała się być próba realizacji projektu Paktu Śródziemnomorskiego. Idea podpisania regionalnego paktu o wzajemnej pomocy, opartego na zasadach zawartych w Pakcie Ligi Narodów po raz pierwszy pojawiała się w dyskusjach ekspertów podczas konferencji w Londynie w 1930 r., w trakcie której dyskutowano o uregulowaniu zagadnień związanych $\mathrm{z}$ wielkością flot wojennych jej uczestników. Delegacja francuska uzależniła wtedy wyrażenie zgody na redukcję programu rozbudowy marynarki wojennej od utworzenia systemu wzajemnych gwarancji, w sklad którego wejść miały państwa śródziemnomorskie i podpisania dodatkowych umów z Wielką Brytanią. Ponieważ nie doszło do porozumienia w tej sprawie, Francuzi ostatecznie odmówili podpisania układu o zbrojeniach morskich ${ }^{29}$. Sześć lat później Quai d’Orsay wróciło do przedstawionego w Londynie pomysłu stworzenia paktu, który połączyć miał państwa basenu Morza Sródziemnego i na jego podstawie stworzyło zarys stosownej umowy międzynarodowej. Była to jedna $z$ prób odtworzenia i rozbudowania francuskiego systemu bezpieczeństwa, który w swojej dotychczasowej wersji praktycznie przestał istnieć po remilitaryzacji Nadrenii. Podjęta ona została równolegle $z$ trwającymi od połowy $1936 \mathrm{r}$. staraniami o podpisanie nowych porozumień między państwami - sygnatariuszami umów z Locarno, co było bardzo trudne między innymi ze względu na istnienie paktu francusko-radzieckiego. $Z$ drugiej strony Moskwa patrzyła bardzo niechętnie na wszelkie plany stworzenia paktów, które połączyć miały jedynie państwa Europy Zachodniej. Dodatkowo, sytuację międzynarodową mocno skomplikował wybuch wojny domowej w Hiszpanii i próby interwencji podejmowane przez niektóre państwa europejskie. Ze względu na te wydarzenia, zagadnienia związane $z$ możliwościami żeglugi po Morzu Sródziemnym, które mogło posłużyć jako szlak komunikacyjny z Hiszpanią, zyskały nowe znaczenie.

W lipcu 1936 r. propozycję umowy między państwami basenu Morza Śródziemnego przedstawiono początkowo jedynie Brytyjczykom. Jego uczestnikami miały być: Francja, Wielka Brytania, Włochy, Hiszpania, Jugosławia, Turcja i Grecja. W memorandum przedstawiającym najważniejsze punkty umowy zapisano również, że Francuzi życzyliby sobie, aby pakt objął także państwa czarnomorskie, a wśród nich ZSRR w tych punktach, które mogly ich dotyczyć. Głównym celem porozumienia miała być ochrona granic morskich i wysp należących do państw - sygnatariuszy, a także zapewnienie im bezpiecznej i nieograniczonej możliwości komunikacji na Morzu Śródziemnym. Jego postanowienia miały być powiązane

${ }^{2 \pi}$ DDF, II, t. 3, dok. 146.

${ }^{29}$ DDF, II, t. 2, dok. 461; Historia dyplomacji, red. A. A. Gromyko i in. t. III: 1914-1939, red. W. M. Chwostow i in., Warszawa 1973, s. 588-589. 
z systemem bezpieczeństwa Ligi Narodów ${ }^{30}$. Szczególnie istotne z punktu widzenia sojuszu francusko-radzieckiego mogły być postanowienia mające uregulować sprawy żeglugi i komunikacji. W Foreign Office uważano w tym czasie, że projekt francuski nie miał szans realizacji w związku $z$ ówczesną napiętą sytuacją międzynarodową. Najważniejszą przeszkodą miał być - według dyplomatów brytyjskich - problem Włoch, wobec których Liga Narodów kilka dni wcześniej zniosła sankcje, nałożone $\mathrm{z}$ powodu ich ataku na Etiopię ${ }^{31}$. Francuzi nalegali jednak na rozpoczęcie rozmów w sprawie paktu i oświadczyli na początku sierpnia $1936 \mathrm{r}$., że jeżeli Wielka Brytania nie wyrazi nimi zainteresowana, przedstawią swoją propozycję innym rządom ${ }^{32}$. Według wspomnień Anthonego Edena, przedstawiciele Francji mieli wypowiadać się w podobnym tonie podczas spotkania Zgromadzenia Ligi Narodów, $w$ trakcie którego po raz kolejny proponowali wznowienie rozmów na temat Paktu Śródziemnomorskiego. On sam miał być temu przychylny ${ }^{33}$. W kolejnych komentarzach do projektu przedstawiciele rządu brytyjskiego wskazywali jednak na problemy, które ich zdaniem zdecydowanie utrudniały zawarcie porozumienia. Jednym $z$ nich miała być niechęć Londynu do udziału ZSRR w pakcie ${ }^{34}$. W odpowiedzi Delbos stwierdzil, że udział Związku Radzieckiego w pakcie nie był konieczny i zależnie od dalszych dwustronnych ustaleń możliwe było ograniczenie porozumienia jedynie do krajów leżących nad Morzem Śródziemnym. Podkreślał, że stanowisko rządu francuskiego w tej sprawie nie zostało jeszcze do końca sprecyzowane, co dawało możliwości do dalszych dyskusji ${ }^{35}$. Była to widoczna zmiana postawy wobec spraw śródziemnomorskich w porównaniu ze staraniami, które podejmowali przedstawiciele rządu francuskiego dwa miesiące wcześniej, podczas konferencji w Montreux. Ukazywała ona brak determinacji dyplomatów francuskich, aby włączyć wschodniego sojusznika do systemu umów pokojowych, który starał się stworzyć Paryż, a także, aby ostatecznie zagwarantować istnienie szlaku komunikacyjnego między aliantami. Wskazywała ona również, podobnie jak wiele innych działań Francuzów tego okresu, na wyraźnie priorytetowe traktowanie stosunków Paryża z Londynem, przy jednoczesnym pomijaniu znaczenia sojuszy wschodnich. Wielka Brytania nie była jednak gotowa na całkowite pominięcie czynnika rosyjskiego $w$ dyskusjach o projektowanym pakcie. Z rozmów przeprowadzonych na początku października $1936 \mathrm{r}$. przez ambasadora francuskiego z przedstawicielem Foreign Office wynikało, że Brytyjczycy, w przeciwieństwie do Francuzów, uważali udział Związku Radzieckiego w pakcie $z$ jednej strony za konieczny, ze względu na istniejące obawy państw basenu Morza Śródziemnego, związane $z$ możliwym wpłynięciem floty radzieckiej na jego wody, $z$ drugiej natomiast za zdecydowanie utrudniający negocja-

\footnotetext{
${ }^{30}$ DDF, II, t. 2, dok, 461 .

${ }^{31}$ DDF, II, $\mathrm{t} .3$, dok. 31 .

${ }^{32}$ Ibidem, dok. 121.

${ }^{33}$ A. Eden, Pamiętniki 1932-1938, t. 1, W obliczu dyktatorów, Warszawa 1970, s. 331.

${ }^{34}$ DDF, II, t. 3, dok. 147.

${ }^{35}$ Ibidem, dok. 278.
} 
cje, głównie z powodu napięcia włosko-radzieckiego, spowodowanego sprawami hiszpańskimi. Od początku sierpnia $1936 \mathrm{r}$. kraje te wzajemnie się oskarżały o dostarczanie uzbrojenia dla jednej ze stron wojny domowej w Hiszpanii. Ich konflikt był jednym $z$ elementów procesu powstawania na arenie międzynarodowej dwóch bloków państw biorących pośredni i bezpośredni udział w hiszpańskich działaniach wojennych. $Z$ tej i kilku innych przyczyn Wielka Brytania zdecydowała się przesunąc w czasie rozpoczęcie dyskusji na temat projektu przedstawionego przez Paryż. Ambasador francuski interpretował jednak to stanowisko jako całkowity brak poparcia Londynu dla idei zawarcia Paktu Śródziemnomorskiego, co miało się łączyć - jego zdaniem - z zainteresowaniem Brytyjczyków przede wszystkim osiągnięciem porozumienia $z$ Włochami i zachęceniem ich do aktywnego udziału $w$ tworzeniu nowych porozumień lokarneńskich ${ }^{36}$. Opinię tę potwierdziły kolejne działania Wielkiej Brytanii podejmowane na arenie międzynarodowej.

W połowie listopada możliwość udziału tego państwa w wielostronnym Pakcie Śródziemnomorskim znacznie się zmniejszyła ze względu na rozpoczęcie dwustronnych negocjacji brytyjsko-włoskich, dotyczących uregulowania spraw morskich. Wedlug doniesień prasowych miało być to efektem postawy Mussoliniego, który był bardziej zainteresowany podpisaniem porozumienia między dwoma wpływowymi krajami, niż negocjowaniem paktu o większej liczbie uczestników. Strona francuska wyrażała jednak swoje zdziwienie postawą Brytyjczyków, którzy podczas wcześniejszych rozmów niejednokrotnie wyrażali przywiązanie do porozumień wielostronnych, a także zapewniali przedstawicieli Paryża o zainteresowaniu dla zgłaszanych przez nich pomysłów ${ }^{37}$. W ciągu kolejnych tygodni, kiedy Foreign Office potwierdzilo doniesienia o rozmowach $z$ Wlochami, dyplomaci francuscy wyrażali życzenie wzięcia w nich udziału, nawet gdyby planowane porozumienie miało objąć tylko trzy kraje. Brytyjczycy nie uważali jednak tego za możliwe ${ }^{38}$. W związku z dalszymi prośbami Francuzów, zdecydowali się oni jednak na początku grudnia ostatecznie ustosunkować do projektu Paktu Sródziemnomorskiego. W nocie przedstawiającej analizę kolejnych punktów umowy jeszcze raz podkreślono konieczność udziału ZSRR w planowanym porozumieniu. Motywowano to między innymi sytuacją Turcji, która - zdaniem Londynu - nie byłaby gotowa związać się żadnym porozumieniem bez udziału Rosjan. Dalej zaznaczono jednak, że $w$ związku $z$ istnieniem $w$ dalszym ciągu napięć między ZSRR i innymi potencjalnymi uczestnikami paktu, jego podpisanie, a nawet prowadzenie negocjacji z nim związanych było niemożliwe $e^{39}$.

Ostatecznie francuski projekt przestał mieć rację bytu na początku $1937 \mathrm{r}$. Dnia 2 stycznia przedstawiciele Londynu i Rzymu, po zakończeniu rozmów prowadzonych do końca grudnia 1936 r., podpisali dwustronną umowę regulującą stosunki między tymi krajami w sprawach Morza Śródziemnego. Stwierdzono

\footnotetext{
${ }^{36}$ Ibidem, dok. 314.

${ }^{37}$ Ibidem, dok. 485, 489.

${ }^{38}$ Ibidem, dok. 511.

${ }^{39}$ DDF, II, 6. 4, dok. 87.
} 
w niej, że nie istniały między nimi żadne różnice interesów w sprawach morskich, a także zapowiadano utrzymanie status $q u 0^{40}$. Potrzeba zawarcia szerszego poro zumienia przestała dla nich istniec. $Z$ punktu widzenia Francji podpisanie jakiegokolwiek porozumienia, które nie objęłoby Wielkiej Brytanii i Włoch, nie mogło w pelni zagwarantować bezpieczeństwa jej granic.

Przyblizona powyżej treść not francuskich i brytyjskich, choć dotyczących projektu, który w rzeczywistości nie odegral żadnej roli wówczesnych stosunkach międzynarodowych, ukazuje bardzo wyraźnie priorytety polityki zagranicznej Francji widziane przez tworzących ją dyplomatów. Konieczność natychmiastowej regulacji zagadnień mających bezpośredni wpływ na bezpieczeństwo kraju zdecydowanie zakłócała postrzeganie całokształtu polityki europejskiej i wpływała na stosunek do istniejących zobowiązań francuskich. Przykładem tego była gotowość Francuzów do wykluczenia wschodniego partnera z planowanego porozumienia przy okazji tworzenia projektu Paktu Śódziemnomorskiego. Analizy Foreign Office ukazały krótkowzroczność polityków francuskich, których inicjatywa, ze względu na jej ograniczenia, nie miała szans realizacji w zmieniającej się gwałtownie sytuacji międzynarodowej.

Działania rządu Bluma w sprawach Morza Śódziemnego ukazały między innymi miejsce Związku Radzieckiego w jego polityce zagranicznej. O ile podczas konferencji w Montreux delegaci francuscy próbowali realizować główne postulaty prezentowane przez Bluma na początku jego urzędowania, wśród których znalazło się nadanie praktycznego wymiaru paktowi francusko-radzieckiemu, a także przywiązanie do zasad zapisanych w Pakcie Ligi Narodów, w przypadku projektu Paktu Śódziemnomorskiego dyplomacja francuska odeszła od tych priorytetów. Dzialania związane $\mathrm{z}$ próbami stworzenia wielostronnego porozumienia $\mathrm{W}$ sprawach morskich, które $z$ punktu widzenia relacji francusko-radzieckich i warunków paktu podpisanego przez te państwa w 1935 r. uzupełniałoby postanowienia umowy w sprawie Cieśnin Czarnomorskich, częściowo gwarantującej komunikację między dwoma partnerami, dowiodły gotowości Paryża do odsunięcia na dalszy plan spraw wschodniego sojuszu w przypadku możliwości zapewnienia poządanych gwarancji z ich pominięciem. Starania dyplomatów francuskich o uzyskanie przede wszystkim poparcia brytyjskiego dla swego planu ukazały również wpływ, jaki Londyn wywierał w tym czasie na działania Paryża podejmowane na forum międzynarodowym. Przybliżone tu cechy polityki zagranicznej rządu Bluma w sprawach Morza Śódziemnego w kontekście relacji francusko-radzieckich były charakterystyczne również dla innych inicjatyw podejmowanych przez niego w tym czasie. Mimo planów ożywienia kontaktów Paryża z jego wschodnimi sojusznikami, a wśród nich przede wszystkim rozszerzenia wspólpracy z ZSRR i początkowych prób realizacji tych założeń, gabinet Frontu Ludowego, podobnie jak jego poprzednicy, nie traktowal ich jako głównych priorytetów podejmowanych działań.

${ }^{40}$ Ybidem, dok. 231 i 234; A. Eden, op.cit, s. 331-332. 